\title{
Difficulties Faced By the Rural Students in Learning English at High School Level
}

\author{
Dr.D.Ponmozhi ${ }^{1}$, A.Thenmozhi ${ }^{2}$ \\ ${ }^{1}$ Principal, O.P.R. Memorial College of Education, Vadalur, Tamilnadu, India \\ ${ }^{2}$ M.Ed Student, O.P.R. Memorial College of Education, Vadalur, Tamilnadu, India
}

\begin{abstract}
The article deals with the problems and the difficulties faced by the rural students in learning English. There are many challenges were faced by the rural students in the areas of Speaking, Pronouncing, Communicating and Writing the second language (English). The subject of the study contains 200 students in rural areas were selected randomly. English Learning Difficulty scale constructed and standardized by the researchers is used to collect the data. This study reveals that the English Learning Difficulty at the high school level is high. There exists significant difference between sub samples related to mother's education, Parental occupation, Parental income and Class strength. Furthermore, it was found that among the 11 personal variables 4 variables Class strength, father's education, mother's education and Parental occupation were positive predictors of English Learning Difficulty of rural students and accounted for approximately 23\% variance in English Learning Difficulty of rural students.
\end{abstract}

Keywords: Learning difficulties, Rural students, High School children, Speaking, Pronouncing, Communicating and Writing skill.

\section{INTRODUCTION}

Nowadays knowledge in English were increased in Urban areas, but still the students in rural areas faced many difficulties in learning English at their schools in Speaking, Writing Pronouncing English. The rural students still do not have enough encouragement to practice English. This article analysis the causes that make the students difficulty in English and suggests some solutions that can overcome the difficulties.

\section{Learning Difficulties in English}

Problems and Errors committed by the students in writing Englishis known as learning difficulties. English learning includes Mastering of Listening, Speaking, Reading and Writing skills. The First cause that makes the Students Difficulties in speaking English is that the Environment does not support the students to speak English fluently." Since English is a foreign language in our country, most students especially high school students are not familiar with it, the second causes arestudents Themselves, they does not care for their Communication. There is no interest shown in the areas of learning English by the rural areas of students. The Third causes in SchoolOrganization, they should encourage the students with the sub-coaching to motivate the students.So that teachers easily find the difficulties of students to learn English with the lower level of difficulties. The Fourth cause rarely with The Overloaded Textbook areas.

\section{NEED OF THE STUDY}

The investigator understands the difficulties faced by the rural students of learning English in high school level. There are the most common and specific difficulties to learn English. They faced Difficulties in Pronouncing, Communicating, and Writing of the second language. The investigator classified that the difference of rural education to urban.

\section{OBJECTIVES:}

1. To assess difficulties faced by students in learning English at the high school level

2. To find the relationship between subsamples and difficulties faced by the students in learning English at high school level

3. To find predictor of difficulties faced by students in learning English at high school level

\section{HYPOYHRSIS}

1. The difficulty faced by students in Learning English at the high school level is low.

2. There is no significant relationship between subsamples and difficulties faced by students in Learning English at the high school level.

3. There is no predictor of difficulties faced by students in Learning English at the high school level. 


\section{MATERIALS AND METHODS}

Normative Survey Method has been used. By using Random Sampling Technique 200 high school student selected from Cuddalore district and used as subjects of this study. English Learning Difficulty scale (2017) constructed and standardized by the researchers was used to collect the data from respondents. The Scale comprises of seven sub scales viz; Own nature, School Environment, Sub Coaching, Text book, Method of teaching, Psychological aspects and school administration. Pearson correlation technique and stepwise regression is used to test the hypothesis. The validity and reliability of the scale is $\mathbf{. 6 6}$ and $\mathbf{. 8 1}$ respectively.

\section{ANALYSIS AND INTERPRETATION}

The collected data were analysed with SPSS IBM19 and results were interpreted as below.

\begin{tabular}{|c|c|c|c|}
\hline \multicolumn{4}{|c|}{ Table-1 Percentage analysis of English Learning Difficulty score of the total sample } \\
\hline S.No & $\begin{array}{c}\text { English Learning } \\
\text { Difficulty }\end{array}$ & Score & Percentage \\
\hline 1 & Low & $61-122$ & 0.5 \\
\hline 2 & Moderate & $123-183$ & 19 \\
\hline 3 & High & $184-285$ & 80.5 \\
\hline
\end{tabular}

The above table shows that $\mathbf{8 0 . 5 \%}$ of high school student's English Learning Difficulty is high.

\begin{tabular}{|l|l|l|l|}
\hline Table 2. Mean and Standard Deviation of English Learning Difficulty Score \\
for Total Sample
\end{tabular}

The above table shows the mean score and standard deviation of English Learning Difficulty of high school students. It is found to be 197.88 and 19.09 respectively and concluded that the student's English Learning Difficulty is high.

\begin{tabular}{|c|c|c|c|c|c|c|}
\hline \multicolumn{7}{|c|}{ Table 3. Differential Analysis Of The Total Learning Difficulties Score Of High School Student } \\
\hline S.No: & \multicolumn{2}{|l|}{ Variables } & Mean & SD & t/f value & Result \\
\hline \multirow[t]{2}{*}{1} & \multirow{2}{*}{ Age } & $13-14$ & 198.72 & 17.18 & \multirow[t]{2}{*}{0.92} & \multirow{2}{*}{ NS } \\
\hline & & $15-16$ & 196.06 & 22.75 & & \\
\hline \multirow[t]{2}{*}{2} & \multirow[t]{2}{*}{ Gender } & Male & 200.19 & 21.02 & \multirow[t]{2}{*}{1.82} & \multirow[t]{2}{*}{ NS } \\
\hline & & Female & 195.29 & 16.38 & & \\
\hline \multirow[t]{2}{*}{3} & \multirow[t]{2}{*}{ Locality } & Rural & 199.55 & 19.45 & \multirow[t]{2}{*}{2.83} & \multirow[t]{2}{*}{ NS } \\
\hline & & Urban & 189.45 & 14.72 & & \\
\hline \multirow[t]{2}{*}{4} & \multirow{2}{*}{$\begin{array}{l}\text { No of family } \\
\text { members }\end{array}$} & below 4 & 191.33 & 17.37 & \multirow[t]{2}{*}{-2.58} & \multirow[t]{2}{*}{ NS } \\
\hline & & above 4 & 199.68 & 19.20 & & \\
\hline \multirow[t]{2}{*}{5} & \multirow{2}{*}{$\begin{array}{l}\text { Type of } \\
\text { management }\end{array}$} & Government & 196.71 & 21.23 & \multirow[t]{2}{*}{2.20} & \multirow[t]{2}{*}{ NS } \\
\hline & & Aided & 199.06 & 14.81 & & \\
\hline \multirow[t]{3}{*}{6} & \multirow{3}{*}{$\begin{array}{l}\text { Mother's } \\
\text { education }\end{array}$} & Illiterate & 194.51 & 19.84 & \multirow[t]{3}{*}{3.52} & \multirow[t]{3}{*}{$\mathrm{S}$} \\
\hline & & Literate & 201.32 & 17.68 & & \\
\hline & & Graduate & 208.00 & 22.63 & & \\
\hline \multirow[t]{3}{*}{7} & \multirow{3}{*}{$\begin{array}{l}\text { Father's } \\
\text { education }\end{array}$} & Illiterate & 201.75 & 17.81 & \multirow[t]{3}{*}{2.54} & \multirow[t]{3}{*}{ NS } \\
\hline & & Literate & 196.41 & 20.06 & & \\
\hline & & Graduate & 188.86 & 19.44 & & \\
\hline \multirow[t]{4}{*}{8} & & Private & 191.32 & 27.10 & 2.81 & $\mathrm{~S}$ \\
\hline & Occupation & Governmentt & 193.65 & 16.23 & & \\
\hline & & Business & 198.33 & 17.51 & & \\
\hline & & Cooli & 200.99 & 16.98 & & \\
\hline 9 & Parent Income & Below 5000 & 201.66 & 18.21 & 3.92 & $\mathrm{~S}$ \\
\hline & & $5000-10000$ & 195.60 & 21.38 & & \\
\hline & & $11000-15000$ & 188.75 & 19.09 & & \\
\hline & & $16000-20000$ & 192.43 & 12.79 & & \\
\hline 11 & Class strength & Below 40 & 173.08 & 27.64 & 14.65 & $\mathrm{~S}$ \\
\hline & & Below 50 & 32.00 & 16.00 & & \\
\hline & & Below 60 & 155.00 & 77.50 & & \\
\hline
\end{tabular}


An independent sample $t$ - test showed that the difference in score between different age group of the students is statistically not significant. The difference in score between male and female student is statistically not significant. The difference in score between rural and urban student is statistically not significant. The difference in score between family members with below 4 members and above 4 members is statistically not significant. The difference in score between students studying in different types of management is statistically not significant. The difference in score between illiterate, literate and graduate mother's children is statistically significant. The difference in score between illiterate, literate and graduate father's children is statistically not significant. The difference in score between children with different parental occupation is statistically significant. The difference in score between children with different income group is statistically significant. The difference in score between children studying in different class strength is statistically significant.

\begin{tabular}{|l|r|r|r|r|l|l|}
\hline \multicolumn{7}{|c|}{ Table.4 } \\
\hline Stepwise Regression Between English Learning Difficulties And Other Variables \\
\hline
\end{tabular}

The prediction model contained four of the ten predictors and was reached in sixth steps with 6 variables removed. The model was statistically significant, $F(4,195)=14.581, p<.001$, and accounted for approximately $23 \%$ of the variance in English Learning Difficulties $\left(R^{2}=0.230\right.$, Adjusted $\left.R^{2}=0.214\right)$. English Learning Difficulties is primarily predicted by the lower levels of Parental Occupation, Father's Education, and Mother's Education and to the lesser extent by the higher levels of Class Strength. The raw and standardized regression coefficient of predictors together with their correlation with English Learning Difficulties, their squared semi-partial correlations, and their structure coefficients are shown in table. No-4. The Class Strength received the strongest weight in model followed by Parental Occupation, Father's Education and Mother's Education. Parental Occupation received the lowest weight of the four weights. With the sizeable correlations between the predictors, the unique variance explained by each of the variables indexed by the squared semipartial correlation was relatively low: Parental Occupation, Father's Education, Mother's Education and Class Strength uniquely accounted for approximately $11 \%, 5 \%, 4 \%$, and $2 \%$ of the English Learning Difficulties. Inspection of the structure coefficient suggests that, the Parental Occupation was relatively strong indicators of English Learning Difficulties, and Father's Education, Mother's Education and Class Strength were a moderate indicator of English Learning Difficulties.

\section{Conclusion}

Mother's education, Parent Occupation, Parent Income and Class strength showed significant relationship with English learning difficulties of high school children. The Parental Occupation was relatively strong indicators of English Learning Difficulties, and Father's Education, Mother's Education and Class Strength were a moderate indicator of English Learning Difficulties. The parental occupation decides the quality of life of the family. That itself improves the English learning of the students. The educated parents also educate their children in a better way. Individual attention of the teacher in a class with fewer students also promotes the English learning of the students. So our education administration should follow international guidelines to adopt a system with moderate no of students to give individual attention. Individual difficulties should be identified and remedial measures should be implemented to reduce the Learning difficulties.

\section{Reference}

[1] Abdul RehmanJarlg., Hafiz Ahmed Bilal. \& Muhammed Afzal Sandhu.(2013). Difficulties in Learning English as Second Language in Rural Areas of Pakistan, journal of educational psychological research, $4(6)$.

[2] Ahmed Maher Mahmoud Al Nakhalah.(2016).Problems and Difficulties of Speaking That Encounter English Language Students at Al Quds Open University,International Journal of Humanities and Social Science Invention, 5(12). 
[3] AkramInanlooKhajloo.(2013). Problems in Teaching and Learning English for Students, International Journal of Engineering Research and Development, 7(3).

[4] Elkhair Muhammad IdrissHasan.(2014). English language and literature, Canadian center of Science and Education, 4(4).

[5] Eniko TANKO.(2010).Facing Difficulties in the Acquisition of the English Passive by L1 Speakers of Hungarian,ActaUniversitatisSapientiae, Philologica, 2(2).

[6] Gajalakshmi.(2013). High school students' attitude towards learning English language, International Journal of Scientific and Research Publication, 3(9).

[7] HafsaRiyaz. \&AbanParvazMullick.(2016).Problems in learning English Speaking Skill: A study of Higher Secondary Students in Srinagar, India, International Journal of Interdisciplinary and Multidisciplinary Studies (IJIMS),3(2).

[8] Lai-Mei Leong1 \&SeyedehMasoumehAhmadi.(2017). An Analysis of Factors Influencing Learners' English Speaking Skill, international journal of research in English education, 2(1).

[9] MadhaviLatha.B., \&Pettela Ramesh.(2012).Teaching English as a Second Language: Factors Affecting Learning Speaking Skills, International Journal of Engineering Research \& Technology, 1(7).

[10] Magdalena Aleksandrzak.(2011). Problems and Challenges in Teaching and Learning Speaking At Advanced Level, Glottodidactica, 37.

[11] MajnoAjbani.(2016). Difficulties in Teaching and Learning English Pronunciation in Sindh Province, Pakistan World Academy of Science, Engineering and Technology, International Journal of Cognitive and Language Sciences, 3(8).

[12] Mohamed Alhassan Hassan Mohamed.(2013).Problems of Speaking English Language among University Students (A case study: Education Students), Graduate Studies and Scientific Research,

[13] Mohamed EltayebAbdalla ., \&Elhadi Nasr Elhadi Mustafa.(2015).Problems of Teaching and Learning Spoken English in Sudan, SUST Journal of Humanities, 16(4).

[14] Mona. M. Hamad.(2013). Factors Negatively Affect Speaking Skills at Saudi Colleges for Girls in the South, Canadian Center of Science and Education, 6(12).

[15] Muhammad Dilshad., Masood Ahmad., NarjisTanvir., and FowziaShabbir.(2016). Students' Difficulties in Learning English at Primary Level: A Teachers' Perspective, Journal of Educational Research, 19(1).

[16] Nguyen Hoang Tuan.\&Tran Ngoc Mai.(2015).Factors Affecting Students' Speaking Performance At Le ThanhHien High School, Asian Journal of Educational Research, 3(2).

[17] Nguyen Hoang Tuan., \& Tran Ngoc Mai.(2015).Factors Affecting Students' Speaking Performance At Le ThanhHien High School, Asian Journal of Educational Research, 3(2).

[18] Sana Naway., Aisha Umer., MuffasiraTabasum., \& Maria Zoman.(2015). Difficulties Facing by Learning and Adopting English. European Journal of English Language Linguistics and Literature, 2(2).

[19] WajihaKanwal.\&FauziaKhurshid.(2012).University Students' Difficulties in Learning Language Skills, Language in India, 12(2).

[20] William Dharma Raja,B.\&Selvi ,K.(2011).Causes of Problems in Learning English as a Second Language as Perceived by Higher Secondary Students, i-manager's Journal on English Language Teaching,1(4).

[21] William Dharma Raja.B., Selvi, K.(2011). Causes Of Problems In Learning English As A Second Language As Perceived By Higher Secondary Students, I-Manager's Journal On English Language Teaching,1(4).

[22] YoussoufHaidara.(2016). Psychological Factor Affecting English Speaking Performance for the English Learners in Indonesia, Universal Journal of Educational Research, 4(7).

[23] Zhibo Liu. (2015).Factors affecting English listening and speaking abilities of non-English major students: taking engineering students as an example, World Transactions on Engineering and Technology Education, 13(4). 